2021 GFMC/KSMS at Seoul Proceedings: 177-181 (November 2021)

https://doi.org/10.15444/GFMC2021.03.04.01

\title{
REAL OR VIRTUAL WALKWAY IN LUXURY FASHION CONTEXT?A QUALITATIVE APPROACH
}

\author{
Aihoor Kayoom Aleem, ISCTE - Instituto Universitário de Lisboa and Business \\ Research Unit (BRU-IUL), Portugal ${ }^{1}$ \\ Sandra Maria Correia Loureiro, ISCTE - Instituto Universitário de Lisboa and \\ Business Research Unit (BRU-IUL), Portugal ${ }^{2}$
}

\begin{abstract}
A qualitative study was conducted with the aim of analyzing luxury brands adaptation concerning the Covid-19 impact on the luxury sector. To this end, luxury brand managers from Lisbon were interviewed as a means to collect insights. Our findings indicate that virtual reality was crucial during the pandemic, as stores were closed, and brands needed to sustain their relationships. Managers enhanced social media as a powerful tool as well.
\end{abstract}

Keywords: luxury, immersive technologies, fashion show, Covid-19, interview, qualitative.

\section{INTRODUCTION}

On December $31^{\text {st }}$, 2019, the world completely changed. The World Health Organization (WHO) China Country Office received the first novel coronavirus 2019$\mathrm{nCoV}$ case, in Wuhan, Hubei, China. The current state of the pandemic transformed completely the way we live. In order to survive to this health crisis, it is important to find solutions. Taking into account previous health and economic crisis, the luxury industry found ways to grow. Consumers want to treat themselves with luxury goods and services to celebrate positive life changes. With Millennials and Gen Z being the largest and fastest-growing consumer segments for luxury, this presents an immense opportunity for luxury brands to connect and engage with their customers (Loureiro, Serra and Guerreiro, 2019). In particular, the digital transformation of luxury is essential today, when workforces and consumers alike are in confinement (HerédiaColaço \& Martins, 2021).

As brands needed to adapt to this reality, the inclusion of immersive technologies was crucial for its success. Immersive technologies include Augmented Reality (AR) and Virtual Reality (VR). AR is the experience of actual reality enhanced with virtual images and VR, means a fully immersive experience in a purely virtual world (Rosiński, 2015).

\section{THEORETICAL BACKGROUND}

Luxury has been frequently related with status and admiration, a concept that is covered under the conspicuous consumption literature (Veblen, 1899). This type of consumption

\footnotetext{
1 aihoor.aleem@gmail.com

2 sandramloureiro@netcabo.pt
} 


\section{Global Fashion Marketing Conference at Seoul/ 2021 Korean Scholars of Marketing Science International Conference}

leads consumers to purchase goods/services with the intention of communicating their wealth and status, overcoming the real needs of the consumer (Brun \& Castelli, 2013). For instance, purchasing ostentatious goods such as expensive designer bags with visible logos (e.g., Louis Vuitton, Prada, Hermès). These purchases also provide consumers with sophisticated environments allowing them to get more attached to the brand simply by touching well-crafted goods, tasting champagne and even experiencing tailor-made scents. When this type of experienced is created, consumers become more engaged with the brand leading to a higher willingness to pay (Havlena \& Holbrook, 1986). This sense of pleasure felt by consumers is pointed by prior studies (e.g., Makkar \& Yap, 2018; O'Cass \& McEwen, 2004; Havlena \& Holbrook, 1986), to be associated with hedonic consumption.

According to prior literature, and most recent research (Arienti and Sheehan, 2020) the luxury consumer is changing; therefore, it is very important for luxury brands to serve them as uniquely as possible. Virtual reality usage was one of the tools introduced in their communication strategy (Loureiro et al., 2019; Loureiro et al., 2020; Loureiro et al., 2021). With physical places closed, fashion events had to move to digital places. In the last decade, virtual environments are growing in importance as technological innovation allowed marketers to provide unique consumer experiences. The main goal of using immersive Technologies is to replicate the shopping experience, especially in the luxury market.

\section{METHODOLOGY}

The main goal of this study was gather information with brand managers, regarding the influence of Covid-19 in the luxury sector. Three brand managers - from Louis Vuitton, Prada and Gucci - were interviewed following an unstructured interview method. The managers were interviewed during work hours, inside the store.

Louis Vuitton, Gucci and Prada are located at Avenida da Liberdade in Lisbon. These luxury brands have their own stores not being associated with any other brand in-store. In order to gather the most credible information, we were able to connect with three luxury managers after Christmas, more specifically on December $29^{\text {th }} 2020$.

According to Duarte Carvalho - Prada Men's Department Manager, the luxury brands at Avenida da Liberdade were very impacted by the pandemic, reaching 40 to $50 \%$ profit loss. However, December was the first month Prada did not feel any difference. Irina, from Louis Vuitton confirms that the pandemic had hit the business, but Louis Vuitton was one of the first luxury brands to bounce back after the pandemic. During December, the Lisbon store reached waiting lines of hours, and even appointments with client advisors were full in the majority of the days. The majority of the products were out of stock, not only because the demand was high but, because the production in Europe was very slow during 2020. With focus on the international market, Duarte and Irina both confirm that China and Middle East profits boomed after the pandemic, due to high demand, reaching the point of having to close the store before closing time, not having enough stock to meet customer demand.

Gucci manager shared his concerns for the Lisbon market. The Lisbon store works as a showroom, with very low stock and most of the products needs an order from the customer. With sales going down, Gucci started to implement virtual reality in their 


\section{Global Fashion Marketing Conference at Seoul/ 2021 Korean Scholars of Marketing Science International Conference}

communication strategy. To connect with consumers, the brand started to increase the engagement. The manager states that this modification was what led Gucci to start creating trends online.

The three interviewed managers agree upon the fact that the fashion market was able to find a new source of revenue during the pandemic. For instance, through the introduction of immersive technologies. Louis Vuitton and Prada are testing a new feature named virtual mirror, in which consumers can try clothes, shoes and sunglasses. Gucci is now implementing AR usage through apps such as Roblox and VRChat.

The three interviewed managers enhance the importance of online market, even though it is where most counterfeit purchases happen. Following the online market, the managers state the evolution of virtual reality and artificial intelligence. Louis Vuitton, Prada and Gucci shared their fashion shows through virtual reality tools, helping consumers to disconnect from the pandemic reality. Consumers were usually contacted through WhatsApp and invited to assist to the newest collection. Sales started to increase and the relationship between brand and consumer was sustained. For example, Louis Vuitton created partnerships with Gen $\mathrm{Z}$ famous celebrities, in a way to influence the youngest generation. Thus, adapting the strategy to the pandemic consequences.

\section{CONCLUSION AND FUTURE OUTLOOK}

Even though the pandemic had tremendous consequences for luxury brands, it also helped managers to adapt to the youngest generation and find new sources of revenue. The three brands studied were available in Lisbon, which contributed positively for our collection of insights.

To begin with, Louis Vuitton, Gucci and Prada started to communicate online in a more effective way. Through this approach, new targets were created, and new trends developed. The adaptation to a younger generation was crucial to the brands success during the pandemic (e.g., Gen Z). Another very important factor was the integration of AR and VR, which also helped consumers to share their favorite looks from Fashion Shows, thus, increasing brands engagement and future sales. Specifically, the managers enhanced that the future of fashion shows and new collection presentation tend to move to the virtual space. One major benefit of using immersive technologies is the costbenefit in reaching consumers in a more effective and fast way.

Besides the relevant insight regarding our study, we identify several limitations and future perspective studies to strength our results. Taking into consideration our results, it would be interesting to further understand the impact of pandemic impact in other cities, for example, Madrid and London. Other methods should be included to analyze the impact of virtual reality in luxury purchases as well. For instance, a lab setting to investigate the power of virtual reality ads or fashion shows in consumer attitudes.

The author acknowledges the financial support of FCT - Portuguese Foundation of Science and Technology- BRU-IUL / BRU-ISCTE Doctoral Merit Grant 2019/2022.

\section{REFERENCES}

Abdullah, M., Dias, C., Muley, D., \& Shahin, M. (2020). Exploring the impact $\mathrm{s}$ of COVID-19 on travel behavior and mode preferences. Transportation Re 


\section{Global Fashion Marketing Conference at Seoul/ 2021 Korean Scholars of Marketing Science International Conference}

search Interdisciplinary Perspectives, 8, 100255.

Arienti, P., Sheehan, E. (2020), Global powers of luxury goods 2020 - The ne $w$ age of fashion and luxury. Retrieved from: https://www2.deloitte.com/con tent/dam/Deloitte/at/Documents/consumer-business/at-global-powers-luxury-goo ds-2020.pdf. Accessed January 10, 2021.

Arora, A. S., \& Sanni, S. A. (2018). Ten Years of 'Social Media Marketing' Research in the Journal of Promotion Management: Research synthesis, em erging themes, and new directions. Journal of Promotion Management, 1-2 4. doi:10.1080/10496491.2018.1448322

Brun, A., \& Castelli, C. (2013). The nature of luxury: a consumer perspective . International Journal of Retail \& Distribution Management, 41, (11/12), 8 23-847, https://doi.org/10.1108/IJRDM-01-2013-0006

Hagtvedt, H., \& Patrick, V. M. (2009). The broad embrace of luxury: Hedonic potential as a driver of brand extendibility. Journal of Consumer Psycholog $y, 19(4), 608-618$.

Haigh, R. (2020). Luxury \& Premium 502020 Ranking. Retrieved from: https: //brandirectory.com/rankings/luxury-and-premium/table. Accessed June 1, 202 1.

Havlena, W. J., \& Holbrook, M. B. 1986, The varieties of consumption experi ence: comparing two typologies of emotion in consumer behavior. Journal of consumer research, 13(3), 394-404

Herédia-Colaço, V., \& Rodrigues, H. (2021). Hosting in turbulent times: Hoteli ers' perceptions and strategies to recover from the Covid-19 pandemic. Inter national Journal of Hospitality Management, 94, 102835; https://doi.org/10.1 016/j.ijhm.2020.102835

Holbrook, M. B., (1982). Hedonic Consumption: Emerging Concepts, Methods and Propositions. Journal of Marketing, 46(3), 92-101.

Jain, S., \& Mishra, S. (2020). Luxury fashion consumption in sharing economy : A study of Indian millennials. Journal of Global Fashion Marketing, 11(2 ), 171-189. https://doi.org/10.1080/20932685.2019.1709097

Ko, E., Costello, J. P., \& Taylor, C. R. (2019). What is a luxury brand? A ne $\mathrm{w}$ definition and review of the literature. Journal of Business Research, 99, 405-413.

Loureiro, S.M.C., Guerreiro, J., \& Ali, F. (2020). 20 years of research on virtua 1 reality and augmented reality in tourism context: A text-mining approach. Tourism Management, 77104028 https://doi.org/10.1016/j.tourman.2019.104 $\underline{028}$

Loureiro, S.M.C., Guerreiro, J., \& Tussyadiah, I. (2021). Artificial Intelligence i $\mathrm{n}$ Business: State of the Art and Future Research Agenda. Journal of Busi ness Research, 129, 911-926. doi: 10.1016/j.jbusres.2020.11.001

Loureiro, S.M.C., Guerreiro, J., Eloy, S., Langaro, D., \& Panchapakesan, P. (20 19). Understanding the use of Virtual Reality in Marketing: A text miningbased review, Journal of Business Research, 100, 514-530 doi:10.1016/j.jbu sres.2018.10.055

McFerran, B., Aquino, K., \& Tracy, J. L. (2014). Evidence for two facets of $p$ ride in consumption: Findings from luxury brands. Journal of Consumer Ps ychology, 24(4), 455-471.

O'Cass, A., \& McEwen, E. (2004). Exploring consumer status and conspicuous consumption. Journal of Consumer Behavior, 4(1), 25-39;

Rosiński, Ł. (2015). Report on the current state of the VR market. Retrieved $f$ 
rom http://thefarm51.com/ripress/VR_market_report_2015_The_Farm51.pdf Veblen, T. [1899], (1994). The theory of the leisure class. $\bar{R}$ eprint, New York: Penguin Books.

Vigneron, F., \& Johnson, L. W. (2004). Measuring Perceptions of Brand Luxur y. Journal of Brand Management, 11(6), 484-506. https://doi.org/10.1057/pal grave.bm.2540194 